\title{
Commoning and climate justice
}

\author{
by Patricia E. (Ellie) Perkins \\ Professor, Faculty of Environmental Studies \\ York University, Toronto, Canada \\ esperk@yorku.ca
}

\begin{abstract}
Revised chapter submitted August 5, 2019 for inclusion in Making commons dynamic: Understanding change through commonisation and decommonisation, edited by Prateep Nayak

Routledge Studies in Environment, Culture, and Society Series
\end{abstract}

\begin{abstract}
Commoning represents a dynamic and emergent means of risk-reduction and livelihood provision which can address the shortcomings of both market and state-oriented economic systems -- increasingly relevant as climate change threatens human subsistence worldwide. This paper brings together international examples of responses to climate-related threats that are collective (not privatizing), to provide preliminary empirical evidence about how and in what circumstances people may develop equitable communal institutions rather than ones that worsen community fragmentation. The examples include traditional and new forms of commons which help to meet local subsistence needs and develop communities' social, political and economic resilience in the face of climate change, exploring how climate justice -improving the local and global equity of climate change impacts and processes - can advance in parallel with commons development.

Drawing on the literatures of ecological economics, political ecology, community development, equity studies, disaster management, psychology, ecofeminism, and Indigenous studies as well as the work of commons practitioners and theorists to situate these ideas, this paper advances a framework for comparing communities" climate resilience in terms of collective "commonsreadiness." The indicators involved in this framework include the community's openness/boundaries, historical experiences and aptitudes with collective governance, social networks and social learning, political and economic interdependence, diversity, income distribution, and cultural factors.
\end{abstract}

KEYWORDS: commoning, community resilience, community development, climate justice, climate risk reduction, social capital, participatory governance, ecological economics, political ecology, equity, ecofeminism, social learning, subsistence, livelihoods 


\section{Introduction}

As a settler and an immigrant in Canada, I acknowledge and thank the First Nations and Indigenous peoples of the territories where I live and work: the Anishinaabe, Haudenosaunee, Huron-Wendat, and many other First Peoples. Their gifts, traditions and ongoing climate justice leadership inspire reciprocity.

A recent, sobering book by James Daschuk tells the story of the six years from 1885 to 1891 in which at least a third of the Indigenous population of the Canadian plains died of disease and starvation (Daschuk 2013). During this period, many communities held matahitowin, or the Give-Away Dance, a sacred dance for Pahkahkos, the spirit of famine, in which people gave away everything they had in order to change their fortune. We may all be entering into a new period of crisis and insecurity due to climate chaos. Will our first reaction be to give away and share what we have?

For some cultures, such a response to calamity is natural. Culture and governance traditions play a key role in material and psychic well-being. The greed and selfishness that we often assume are 'human nature' may not be as deeply-engrained as we think. I believe this has important implications for commoning, which depends on sharing well-governed common pool resources and works best when giving is respected and socially rewarded so that there can be "reciprocity between what is given and what is taken" (Federici and Caffentzis 2014:1102).

Indigenous economist Ronald Trosper states, "The world is in the midst of a change in thinking... Climate change is showing that the world depends on a common pool resource, the atmosphere. Other common pool resources, such as fresh water and forests, are also important. Simply put, the world is discovering that people depend upon these common pool resources more than they believed.. How should people organize themselves when they depend upon a common pool resource? We need to study examples of people who have developed complex and productive systems using a common pool resource as the fundamental source of wealth" (Trosper 2009:4). Indigenous peoples on the Pacific Coast developed complex socio-politicalcultural systems centred around the potlatch, a ceremony where leaders demonstrated and confirmed their status by respectfully distributing wealth to all community members (Trosper 2009; Umeek 2011). "The chief shows his worthiness by generating the surplus required for the feast, and the guests acknowledge his position when they accept the gifts" (Trosper 2009:20). Or as Nuu-chah-nulth hereditary chief Umeek says, "... (G)iving is associated with abundance, whereas not giving is associated with stagnation (since the circulation, or giving, of goods and assistance is essential to life)" (Umeek 2011:152).

The embeddedness of commons in appropriately rich social systems is essential to their successfully creating resilient livelihood conditions. Elinor Ostrom's exploration of the requirements for commons governance -- high levels of general civic consciousness, cooperation, the ability to listen and mediate differing goals, conflict resolution, flexibility and good will throughout society, especially in the context of social dynamism and diversity approaches this from an empirical settler stance (Ostrom 2012). Federici and Caffentzis, in seeking to build anti-capitalist commons that prefigure a new mode of production grounded in 
collective solidarity, focus on a different set of indicators: the collective co-production of commons by those whose livelihoods depend on them; shared natural or social resources for non-commercial use that are held in common, not as public goods; also, the gradual reappropriation of public wealth created by communities and public workers; the existence of a community which does care-work to reproduce and regenerate the commons; regulations that stipulate how shared wealth must be used and cared for; and equal access and egalitarian decision-making for all commons members (Federici and Caffentzis 2014:1101-i103).

In this chapter, my goal is to explore these sorts of indicators, preconditions, or opportunities for commoning processes, specifically in relation to climate justice - which is simultaneously a visionary hope that human beings can find a way to reduce climate change fairly, an activist movement aiming to bring this about, and a field of research focusing on how this might happen. Commoning in the face of climate chaos involves building the institutions that, as Ostrom said, can "bring out the best in people," since all humans are in this crisis together even though just a few are mainly responsible for causing it. For many, reforming capitalism and its supporting structures would not be desirable, as this would leave the door open for future climate crises in coming years; only a significantly new system offers hope of a more sustainable and egalitarian livelihood provisioning system.

Co-operatives and commons - used here as linked concepts ${ }^{1}$-- are more prevalent and more important in assuring people's livelihoods globally than many may realize. The United Nations has estimated that the livelihood of half the world's population is made secure by co-operative enterprises (COPAC 1999:1). At some level, thus, it is arguable that commons are widely understood as backstop livelihoods protection when times get difficult.

While it is not inevitable, those dependent on commons are often the most marginalized; this may be because resources valuable enough for private capital and entrepreneurs to take an interest in might not remain commons for long. Countering pressure to privatize anything seen as valuable under capitalism, collective economic structures such as mutual aid, utopian communities, grassroots collaborative economic initiatives and co-ops have allowed Black Americans to persevere in "finding alternative economic strategies to promote economic stability and economic independence in the face of fierce competition, racial discrimination, and White supremacist violence and sabotage" while building leadership and community stability (Gordon Nembhard 2014:28). This underscores the insurgent potential of commons to safeguard community livelihoods against threats from outside / dominant economic interests; the Brazilian quilombos discussed below provide another example.

Understanding commons in their complex historical and anticolonial context is key to equitable economic transformation. Colonial and capitalist economic structures developed together, forcing Indigenous peoples and racialized peoples to bear the brunt of enclosures, slavery, land

\footnotetext{
${ }^{1}$ Greig De Peuter and Nick Dyer-Witheford, in linking cooperatives and commons, explain that cooperatives help workers and community members learn the art of collective association, build decentralized control of common resources, and become integrated in broader currents of social change. "Cooperatives can be seen as a response, at once antagonistic and accommodative, to capitalism... (but) the extension and actualization of the radical potential of worker cooperatives requires interconnection with other commons struggles - a process we term the circulation of the common" (De Peuter and Dyer-Witheford 2010:32).
} 
theft and other forms of exploitation which ultimately led to the climate crisis. Untangling these destructive intertwined systems, in processes of commoning, requires solidarity and strategy. Dene activist Glen Coulthard, in his book Red Skin White Masks, discusses the hope and the promise of commons.
"What must be recognized by those inclined to advocate a blanket 'return to the commons' as a redistributive counterstrategy to the neoliberal state's new round of enclosures, is that, in liberal settler states such as Canada, the 'commons' not only belong to somebody - the First Peoples of this land - they also deeply inform and sustain Indigenous modes of thought and behaviour that harbour profound insights into the maintenance of relationships within and between human beings and the natural world built on principles of reciprocity, nonexploitation and respectful coexistence. By ignoring or downplaying the injustice of colonial dispossession, critical theory and left political strategy not only risks becoming complicit in the very structures and processes of domination that it ought to oppose, but it also risks overlooking what could prove to be invaluable glimpses into the ethical practices and preconditions required for the construction of a more just and sustainable world order" (Coulthard 2014:12).

Justice-oriented economic transformation requires significant and ongoing education about the damage and legacies of colonialism in order to begin to envision alternative economic institutions that respect the contributions and rights of women and Indigenous peoples, both individually and collectively (David 2010; Tuck 2017).

One definition of commons is: "territorial entities and those resources that are collectively owned or shared between and among populations as well as socio-nature - the air, water, plants, etc. of socio-nature as well as the results of social (re)production and interaction such as knowledge, languages, codes, information" (Chatterton et.al. 2012:610). Another definition is "the organized provision of the essentials of life to all" (Turner and Brownhill 2001:806). But whose collectivity and whose life essentials? Equity and decolonization may be obscured by commons ideas, as Fortier points out: "Projects to reclaim the commons remain ensnared within settler colonial logics in three important ways: through the evasion of complicity in producing and maintaining the structures of colonization, through the attempt to naturalize settler spaces and systems of governance, and through the appropriation of Indigenous territories and ways of being" (Fortier 2017:35). He says the only way to address this is by building co-conspiratorial relationships for decolonization (Fortier 2017:50, 64).

The starting point for this chapter is thus that social justice and equity, far from being assured by commons approaches to livelihoods and governance, must be critically examined as indicators of the legitimacy of emergent collective institutions and processes. Climate change, by heightening the urgency and gravity of livelihood threats for growing numbers of marginalized people, is raising the stakes. Decolonization is enmeshed in both the causes of climate change and in approaches to solutions. The commoning examples in the following section are discussed in relation to climate resilience and the potential they seem to offer for creating co-conspiratorial relationships for decolonization.

II. How can commoning advance climate justice and decolonization? 
Commons scholars and activists are optimistic about the potential of commons and commoning building new commons of diverse kinds - to transform and replace capitalism, protect vulnerable groups from climate threats, and incorporate ecological sustainability in new livelihood initiatives (De Angelis 2017:12-13, 267-270; Bollier and Helfrich 2012; Alldridge 2018; Ostrom 2009b). For example, De Angelis says, "The process of social revolution is ultimately a process of finding solutions to the problems that capital systems cannot solve: .... social justice, a dignified life for all, climate change, environmental disaster... What has become increasingly clear from the various movements in the recent decades, from the Zapatistas in the mid-1990s to the Occupy movement in 2011, is that whatever the alternative put forward by an idiosyncratic section of the movement - whether micro or macro, whether participatory budgets, reconfiguration of social spending by the central state, transition towns, renewable energy cooperatives, self-managed factories, non-criminalised cyber-activism, defence of traditional communities along a riverbed threatened by enclosures, general assemblies, self-managed public squares and so on - they all depended on some form of commons, that is social systems at different scales of action within which resources are shared, and in which a community defines the terms of the sharing, often through forms of horizontal social relations founded on participatory and inclusive democracy" (De Angelis 2017:270).

Esteva similarly emphasizes the diversity, grassroots practicality, and social relationship aspects of new commons, in contrast to "resources" or ownership, thus equating commoning with decolonization. "Modern colonization 'economizes' the commons, that is, transmogrifies then into economics goods, commodities, imposing on them a regime of public or private property and the corresponding norms... Resources and commons are opposed and in fact conflicting conditions" (Esteva 2014:i155).

The following examples of commonisation in the face of changing weather, extreme weather events, food shortages, and other climate-induced threats illustrate how this can take place. While they are very diverse, examining them may yield clues to how they developed, what grounds their success, and how they relate to decolonization.

- In eThekwini / Durban, South Africa, a number of ecosystem reforestation projects covering nearly 80,000 hectares rely on women's work (in collecting and planting indigenous seeds, planting forests, eradicating invasive plants, etc.) and benefit womenheaded households through job creation, entrepreneurship training, and education. Community-based waste management initiatives also generate job creation, improved recycling and waste reduction, poverty alleviation, and reuse of materials - central climate adaptation goals for the city (Gumede 2018:29-30; D'MOSS 2018; C40 Cities 2018). These initiatives involve coalitions among post-colonial local government bodies, community conservation groups, and environmental civil society organizations.

- The World March of Women, an international feminist action movement connecting grassroots groups and organizations working to eliminate the causes of poverty and violence against women, has a long history of organizing collectively and even globally for "bread and roses," with an understanding that capitalism, patriarchy, and war sustain and reinforce each other (Asselin 2010). Their movement links women's groups 
internationally for commoning ("the common good -- food sovereignty -- access to resources .... A long chain of solidarity") (Asselin 2010:14-16) in response to climate change and economic induced threats to water, food sovereignty, commodification of the environment, extraction and cuts in public services. This includes "reparation of the ecological debt owed by industrialized countries, most of which are in the North, to peoples in the South. This debt is the result of the gradual appropriation and looting of natural resources and abusive appropriation of communal spaces such as the atmosphere or the oceans, which has created numerous socio-environmental problems at local levels; (and) support for countries where the consequences of climate change and intensive, chemical based agriculture have increased the effects of natural disasters" (WMW 2009).

- In Brazil, more than 2,600 communities of Afro-descendant Brazilians known as quilombos maintain communal property, farms, work systems, and social organization. Many of these communities have maintained their communal livelihood systems since the $16^{\text {th }}$ century when they were established by self-liberated former slaves. Along with Indigenous communities which make up about 14 percent of Brazil's territory, the rights and commons governance of these "traditional communities" are protected by the 1988 Brazilian constitution and by Presidential Decree 6040 of 2007 (FUNAI 2017; Programa Brasil Quilombola 2013), although they remain under threat from extraction, development, ecological and population pressure.

- Lakes in Bangalore, India provide shared drainage, irrigation, micro-climate moderation, waste treatment, water supply, and other benefits for local populations. Rajapalayam Lake, following large-scale privatization and the exclusion of many community members who formerly had access to the common lake, more recently has been the focus of a "recommoning" effort by local activists who have worked with "a wide range of actors from inside and outside government and the local geography... through claiming the public sphere of urban governance" to reassert common rights to the lake (Sundaresan 2001:78).

- Land and housing movements in many countries organize landless and homeless people to claim urban and rural space for houses, farms and communal access. They resist forced removal of poor people's settlements, carry out demonstrations and marches, occupy unused land, push for public housing, set up mutual aid services, and organize schools and universities. These movements include Abahlali baseMjondolo (South Africa), the Landless Workers' Movement (Brazil), Narmada Bachao Andolan (India), EZLN (Mexico), Fanmi Lavalas (Haiti), Bhumi Uchhed Pratirodh Committee (India), and many others.

- Inspired in part by the people's movement in Cochabamba to oust Bechtel as designated private water provider after it drastically raised water prices (Oliveira 2004), a coalition of citizens' groups and local co-operatives called Initiative 136 in Thessaloniki, Greece has fought the privatization of the city's water system by the French water corporation Suez, in order to keep the water in public hands (Swift 2014; Moss 2013; see also Municipal Services Project 2018).

The following are a few additional examples of organizations and projects in Toronto which are building local commons and also addressing social resilience, food insecurity, local 
redistribution, and political change to meet common needs. These groups and initiatives are thus advancing climate justice in the face of climate change and livelihood threats.

- The Parkdale Neighbourhood Land Trust works to protect the social, cultural and economic diversity of Toronto's Parkdale neighbourhood which is facing pressures from development, gentrification and infrastructure erosion. The Trust leases land to nonprofit partners who provide affordable housing and spaces for social enterprises, recreation, and urban agriculture. It promotes food security, poverty alleviation, and community participation in local land-use decisions to keep the area affordable and diverse (PNLT 2018).

- Not Far From The Tree puts Toronto-grown fruit to good use by picking and sharing it locally. Fruit trees planted long ago in the city are still producing apples, pears, cherries, berries, and other fruit. According to the organization's website, "When a homeowner can't keep up with the abundant harvest produced by their tree, they let us know and we mobilize our volunteers to pick the bounty. The harvest is split three ways: $1 / 3$ is offered to the tree owner, $1 / 3$ is shared among the volunteers, and $1 / 3$ is delivered by bicycle to be donated to food banks, shelters, and community kitchens in the neighbourhood so that we're putting this existing source of fresh fruit to good use.... This simple act has profound impact. With an incredible crew of volunteers, we're making good use of healthy food, addressing climate change with hands-on community action, and building community by sharing the urban abundance" (Not Far from the Tree website, 2013).

- The Yes In My Backyard (YIMBY) program links volunteers and land-owners in Toronto. "YIMBY is a garden-matching program that connects gardeners and yardowners in the neighbourhood. Eligible gardeners and garden hosts within the catchment area ... are able to specify what they are looking for in a garden match: Would they like to work together, or have the gardener take care of the space? How would they like to share the produce? .... In addition to finding the perfect garden match, YIMBY offers bulk-buying opportunities, a seedling giveaway, gardening workshops, potlucks, a toolshare, and a seed library... Why wait in line for a community garden plot or watch your yard go to weeds when there's a YIMBY match just around the corner?" (YIMBY 2018).

- Community supported agriculture farms exist across Canada and in many other countries around the world. Food consumers purchase a share of each year's mixed vegetable crop at the beginning of the growing season, providing cash up-front for farmers and spreading the risks and rewards of agriculture. In some CSAs, consumers also help out in the fields. An Ontario website provides a directory of CSA farms across the province so that potential customers can find one in their area (Community Supported Agriculture website 2018).

The same skills of collaboration and negotiation across diversity to build flexible and sustainable governance structures in times of climate chaos are also being mobilized at regional and global scales.

- The nonprofit Marine Conservation Institute brings together scientists, local conservation groups and activists, and governments to advocate for transboundary protection of 
oceans, and is working with government officials, activists and conservation organizations to publicize and begin organizing a "Baja to Bering" ocean conservation corridor, including important offshore biological diversity conservation sites in the Pacific (Marine Conservation Institute 2018).

- Great Lakes Commons is an "activist bioregional initiative working to transform water governance in the Great Lakes along the lines of governance principles rooted in Indigenous traditions, through education, community building, visioning and storytelling, developing respect and understanding of water commons, and networking in the watershed. Questions of justice related to water access, affordability, rules, agency, authority and culture are central to the Great Lakes Commons Charter, an agreement calling for renewed attention to the waters and their governance, which can be used to focus decolonization and climate justice activism" (Baines 2019).

These diverse, brief examples indicate, at different scales, how commons can be assembled, managed, enjoyed and governed by groups of people using a combination of NGO, government, and private structures, rules, and incentives. Each is different, each has its own constituency and provides distinct services or generates value for its members or "commoners". When considered broadly, these benefits extend beyond the commoners to others in society, which is partly what motivates the commons' development and existence, and also shows why commons fill important gaps in state or private/market forms of governance.

Themes that emerge from these wide-ranging cases include:

1) Job creation for the underemployed, particularly women and youth, allows skills to be used and developed through social enterprises that meet community needs.

2) People everywhere will mobilize to protect their common access to necessities of life: water, housing, land, food, space.

3) Marginalized people (ex-slaves, the racialized, ethnic minorities, Indigenous people, women) often have deep historic traditions of commons, skills, and experience with reliance on commons.

4) Multi-scale networking including global partnerships can strengthen commoning movements and initiatives.

5) The many synergies among ecological protection, basic needs provision, food and water sovereignty, education, political engagement, and cultural flourishing are enhanced by and through commoning.

6) Decolonization and post-colonial development can advance in parallel with commoning where Indigenous leadership and cultural traditions are respected and at the forefront.

A commons perspective on climate justice, which Chatterton et.al. term "co-constitutive logics" (2012:607), allows us to use insights from commons theory -- such as the concepts of socioecological systems (SES) and polycentricity -- to identify crucial challenges to climate justice, and find ways to address these challenges. For example, skills of communication, collaboration and respect may need fostering in order to build the potential for commons governance and also climate justice. Where borders and limits are problematic in access to resources by local groups in the context of climate change-induced migration, a focus on access and borders -- perhaps 
ecosystem borders such as watersheds -- may help to encourage a sense of common purpose and internal purpose. At the global scale, where redistribution and dissemination of promising climate justice solutions are desperately needed, respect and solidarity through diaspora communities, ethical commonalities, and polycentricity may be very helpful.

As Chatterton et.al. note, "The commons, then, creates new vocabularies, social and spatial practices and repertoires of resistance which activists are creatively using to challenge a problem as complex as climate change. Commoning evokes a political imaginary which can be anti (against), despite (in) and post (beyond) capitalist." .... What is crucial is that (commons) are prefigurative (i.e. they practice the future that they wish to see), open, experimental and have the potential to generate solidarities" (Chatterton et.al. 2012:611).

Concepts of property rights (which as Escobar notes are problematic in reference to commons) are in constant flux in response to changing social, economic and political circumstances (Demsetz 1967; Carlson 2009:64). As legal scholar Jonathan Carlson points out, "Until scientists discovered the impact of climate change, the international community did not need to consider whether there was a 'right' to emit greenhouse gases or whether there was a right to be free of changes in the chemical composition of the atmosphere caused by greenhouse gas emissions. These issues simply did not arise. Consequently the treatment of the atmosphere and the climate system as unowned commons is a treatment not founded on social judgements about rights but on the previous lack of need for such a judgement" (2009:64). Climate change underscores that it is time to acknowledge the importance of commons as an emergent way of structuring and governing Earth affairs.

Climate justice is itself polycentric, in the sense that there are many ways to move towards it, and local people know best how. Even at the global scale, polycentricity is a useful frame:

1) The same skills and methods (trust, reciprocity, respect, transparency, clear monitoring for compliance) that work locally are helpful globally.

2) Short-term and episodic responses to crises (disease outbreaks, earthquake or storm relief) can be built into long-term, more institutionalized support for local justice initiatives, if this is done concertedly with new frames (beyond State and Market) and led by local people.

3) Diasporic communities have tremendous potential to motivate and facilitate global links and transfers.

4) Opposing fossil fuel use, investment, exploration, extraction and technologies is a global priority (as is developing, fostering and spreading decentralized renewable energy and energy-storage initiatives). Decentralization is potentially more just because it interferes with exploitative global market systems. This is an emergent aspect of the post-fossil fuel era, and it opens the way for local commoning.

5) Indigenous peoples' leadership is powerful; First Nations have deep experience with the damage and destruction of colonialism, are more open to commons, often less enmeshed in the Market, more critical of the State, more culturally and politically creative. They also have moral, historical and legal claims to their traditional territories, and experience with the socio-political requirements for sustainable life there. 
Commons are both an end and a means toward climate justice. To quote Chatterton et.al.: "Exploring, understanding and promoting novel spatial forms constituted through communing practices, then, is central to mobilizing the alternatives that are developing through place-based movements, networks, and translocal alliances for climate justice" (2012:612).

Indigenous activism and scholarship offers guidelines for reconciliation which start with settlers' doing the work required to rectify their ignorance about the colonial repression of Indigenous histories and the damages of colonialism; redressing these wrongs through return of control and decision-making power over Indigenous territories and their wealth; respecting Indigenous knowledge, knowledge-keepers, and diversity in their richness; building ongoing relationships of respect; and prioritizing the land and all its inhabitants (Simpson 2017; Manuel 2017; Coulthard 2014; Tuck and Yang 2012).

No economic or theoretical concepts - including commons, feminism, and climate justice - can be separated from the effects of colonialism. Colonialism, due to its global nature and interdependence with the history of capitalism, has changed human thought patterns as well as all the relationships among humans and other life on Earth (Nixon 2015). Using Western theoretical and even activist frames to attempt to describe co-conspiratorial relationships of decolonization is a bit like trying to use the Master's tools to dismantle the Master's house (Lorde 1979). As we build new commons for livelihood provision in times of climate change, we can find inspiration and hope in the creative collective solidarity that arises from the grassroots, grounded in skills and desires that predate capitalism, colonialism and patriarchy.

\section{Conclusion}

The goal of this chapter was to advance a series of indicators of commons-readiness or commoning opportunities, and to point to how climate justice challenges may create both the need and the desire for commons.

Based on the examples briefly cited above, let me venture the following thoughts. A community's ability to sustainably govern its livelihood-protecting commons (its "commonsreadiness"), and to build co-conspiratorial relationships of decolonization in times of climate change, is positively correlated with:

- Respected Indigenous leaders, elders, languages, and cultural programs

- Ongoing efforts to combat colonialism and redress its legacies through education, and shared traditions

- Community members' recognition of each other, respect for each other, and history together

- Depth of social, cultural, sustenance, and political networks among community members

- Shared socio-cultural values that prioritize sustainable relationships with the land and more-than-human nature

- Social institutions that ensure material redistribution and equity, limit the impunity of leaders, and emphasize relationships of reciprocity

- Dynamic possibilities for social learning by recognizing diverse contributions and perspectives 
- Community flexibility in adapting to new situations within a stable social framework

- Mechanisms for transmitting and developing skills

- Shared recognition of the boundaries for the community's responsibilities

- Interactions, networks, and relationships with other communities

- Transparent information-sharing

- Equitable political / cultural roles for all

- Strategies for meeting outside threats to the community's commons and their governance

Noticing, acknowledging, and assessing these factors in appropriate ways will vary according to each specific situation, and will need to be discussed and derived collectively by community members themselves as they develop their own processes of commoning. 


\section{REFERENCES}

Alldridge, Celia (2018). "How the defense of the commons and territories has become a core part of feminist, anti-capitalist struggles," in Friends of the Earth and C40 Cities, Why Women Will Save the Planet (2nd edition), pp. 141-153 (London: Zed Books).

Anarres (2013). http://anarres.ca/

Accessed 6 January 2014.

Asselin, Michèle (2010). "2010 Women on the March until we are all Free! A Brief History of the World March of Women." https://www.dssu.qc.ca/wp-

content/uploads/a_brief_history_of_world_march_of_women.pdf

Accessed 5 August 2019.

Baines, Paul (2019). "The Great Lakes Commons: working with water and adapting our movement to the Great Lakes." In P.E. Perkins (ed.), Local Activism for Global Climate Justice: The Great Lakes Watershed (London / New York: Routledge), chapter 17.

Bakker, Karen (2007). "The 'commons' versus the 'commodity': alter-globalization, antiprivatization and the human right to water in the Global South." Antipode, vol. 39 no. 3, pp. 430-455.

Bollier, David and Silke Helfich, eds. (2012). The wealth of the commons: a world beyond market and state. Amherst, MA: The Commons Strategies Group / Levellers Press.

Bond, Patrick (2013). "Water rights, commons and advocacy narratives," South Africa Journal on Human Rights, Vol. 29, Iss.1, pp. 125-143.

Broad, Robin and John Cavanagh (2015). "Poorer countries and the environment: friends or foes? World Development 72:419-431.

C40 Cities (2018). "100 resilient cities pilot project: community based interventions to improve river health (Aller River)." http://www.c40.org/case_studies/community-based-interventions-toimprove-river-health

Canadian Co-operative Association (2013). "Co-op facts and figures," CCA website, http://coopscanada.coop/en/about_co-operative/Co-op-Facts-and-Figures. Accessed 29 October 2013. See also: http://www.planetfriendly.net/coop.html http://www.coopscanada.coop/assets/firefly/files/files/Ethnocultural_co-ops_report final.pdf

Carlson, Jonathan C. (2009). "Climate change and the rights of States," Transnational Law and Contemporary Problems 18:45-67.

Cato, Molly Scott (2004). "The Earth is our Mother - What are the economic implications?" Available online: http://www.gaianeconomics.org/pdf/ecofem.pdf 
Accessed 28 October 2013.

Chatterton, Paul, David Featherstone, and Paul Routledge (2009). "Articulating climate justice in Copenhagen: antagonism, the commons, and solidarity. Antipode 35(3)602-620.

Clayton, Susan and Christie Manning (2018). Psychology and Climate Change (Cambridge, MA: Academic Press).

Community Supported Agriculture (2018). http://csafarms.ca/wp/

Co-operative Housing Federation of Toronto (2013). http://www.coophousing.com/ COPAC - Committee for the Promotion and Advancement of Cooperatives (1999). "The Contribution of Cooperatives to the Implementation of the World Summit for Social Development Declaration and Programme of Action" (Geneva: COPAC). Available online: http://www.copac.coop/publications/1999-coops-wssd5.pdf. Accessed 5 November 2016.

Coulthard, Glen Sean (2014). Red Skin White Masks: Rejecting the Colonial Politics of Recognition (Minneapolis/London: University of Minnesota Press).

Creative Commons (2013). http://creativecommons.org/about Accessed 6 January 2014.

Daschuk, James (2013). Clearing the Plains: Disease, politics of starvation, and the loss of aboriginal life (Regina, SK: University of Regina Press).

Davis, Lynne, ed. (2010). Alliances: Re/Envisioning Indigenous-non-Indigenous Relationships. Toronto: University of Toronto Press.

De Angelis, Massimo (2017). Omnia Sunt Communia: On the Commons and the Transformationto Postcapitalism. London: Zed.

De Peuter, Greig and Nick Dyer-Witheford (2010). "Commons and Cooperatives," Affinities: A Journal of Radical Theory, Culture, and Action, 4:1 pp. 30-56.

De Souza Briggs, Xavier (2008). Democracy as Problem-Solving: Civic capacity in communities across the globe. (London/Cambridge: MIT Press).

D’MOSS (2018). Durban Metropolitan Open Space System. http://www.durban.gov.za/City_Services/development_planning_management/environmental_pl anning_climate_protection/Durban_Open_Space/Pages/What-can-you-do-to-protectbiodiversity.aspx

The Ecologist (1992). Special issue: Whose Common Future? Vol. 22, no. 4, July/August. 
Enarson, Elaine, Alice Fothergill and Linda Peek (2006). "Gender and disaster: foundations and directions," in H. Rodrígues, E.L. Quarantelli and R.R. Dynes (eds.), Handbook of Disaster Research (New York: Springer).

Ensor, J. and R. Berger (eds.) (2009). Understanding Climate Change Adaptation: Lessons from Community-Based Approaches. Bourton on Dunsmore, UK: Practical Action Publishing.

Esteva, Gustavo (2014). "Commoning in the new society," Community Development Journal vol. 49 No. 1-1, pp. i114-i159.

Federici, Sylvia (2004). Caliban and the Witch (Brooklyn, NY: Autonomedia).

Federici, Sylvia (2011). "Feminism and the politics of the commons," The Commoner, No. 15. http://www.commoner.org.uk/?p=113

Federici, Sylvia (2018). Re-enchanting the World: Feminism and the Politics of the Commons (Oakland, CA: PM Press).

Federici, Sylvia and George Caffentzis (2014). "Commons against and beyond capitalism," Community Development Journal 49:S1, pp. 192 - i105.

Few, Roger, Katrina Brown and Emma L. Tompkins (2014). "Public participation and climate change adaptation: avoiding the illusion of inclusion," Climate Policy 7(1)46-59.

Fortier, Craig 2017). Unsettling the Commons: Social movements within, against, and beyond settler colonialism. Winnipeg: ARP Books.

FUNAI (2017). “Terras indígenas no Brasil.” http://www.funai.gov.br/index.php/indios-nobrasil/terras-indigenas.

Gordon Nembhard, Jessica (2014). Collective Courage: A history of African American cooperative economic throught and practice (University Park, PA: Pennsylvania State University Press).

Great Lakes Commons (2013). http://www.greatlakescommons.org/ Accessed 6 January 2014.

Great Lakes Commons Map (2013). http://greatlakescommonsmap.org/main Accessed 6 January 2014.

Gumede, Zandile (2018). "What's happening in Durban: From 'tree-preneurs' to trendsetters," in Friends of the Earth and C40 Cities, Why women will save the planet (London: Zed), pp. $27-$ 31.

Harvey, David (2011) “The future of the commons,” Radical History Review 109:101-107. 
Hess, Charlotte and Elinor Ostrom (2007). Understanding knowledge as commons: from theory to practice. Cambridge, MA: MIT Press.

Hyde, Lewis (2010). Common as Air: Revolution, Art and Ownership (New York: Farrar, Straus \& Girous).

IPCC (2007). "Climate change 2007: Appendix to synthesis report". In Climate change 2007: Synthesis report. Contribution of working groups I, II and III to the fourth assessment report of the intergovernmental panel on climate change (Geneva: IPCC).

Jones, Van and Conrad, Ariane (2008). The Green Collar Economy. New York: HarperOne.

Kleres, Jochen and Asa Wwttergren (2016). "Fear, hope, anger, and guilt in climate activism,“ Social Movement Studies, vol. 16, Iss. 5, pp. 507-519.

Kretzmann, John P. and John L. McKnight (1993) Building Communities From the Inside Out (Chicago: ACTA Publications).

Kuyek, Joan N. (1990). Fighting for Hope: Organizing to Realize our Dreams (Montreal/New York: Black Rose Books).

Lickers Xavier, Adrienne (2017). "Longhouse to the Greenhouse: The Path fo Food Security at Six Nations," in Catherine Etmanski (ed.), Food Leadership: leadership and adult learning for global food systems transformation (Rotterdam/Boston/Taipei: Sense Publishers), pp. 3-16.

Lindell, Michael K. (2011). “Disaster studies,” Sociopedia.isa.

http://www.sagepub.net/isa/resources/pdf/disaster\%20studies.pdf

Lorde, Audre (1979). "History is a weapon: The master's tools will never dismantle the master's house.” http://www.historyisaweapon.com/defcon1/lordedismantle.html

Marine Conservation Institute (2018). http://www.marine-conservation.org/what-we-

do/program-areas/mpas/baja2bering/\#sthash.0erSPrqb.dpuf

Accessed October 30, 2013.

MacPherson, Ian (n.d.) "The history of the Canadian co-operative movement: a summary, a little historiography, and some issues." Available online:

socialeconomyhub.ca/sites/...ca/files/Cdian\%20Co-op\%20History.doc

Manuel, Arthur (2017). The Reconciliation Manifesto: Recovering the land, rebuilding the economy (Toronto: Lorimer).

Martinez-Alier, Joan (2012). "Environmental justice and economic degrowth: An alliance between two movements," Capitalism Nature Socialism, Vol. 23 No. 1, pp. 51-73. 
Mellor, Mary (2012). "Cooperative principles for a Green Economy." Capitalism Nature Socialism, vo. 23, iss. 2, pp. 108-110.

Mellor, Mary (1997). Feminism and Ecology. New York: NYU Press.

Mies, Maria (1986). Patriarchy and Accumulation on a World Scale: Women in the International Division of Labour. London: Zed Books.

Mies, Maria and Claudia von Werlhof (1988). Women: the Last Colony (London: Zed Books).

Moss, Daniel (2013). "Greeks stand up to protect their water from privatization." On the Commons, January 8. http://www.onthecommons.org/magazine/greeks-stand-protect-theirwater-privatization\#sthash.RvgrzZqx.dpbs

Municipal Services Project (2018). https://www.municipalservicesproject.org/

Murota, Takeshi and Ken Takeshita (2013). Local commons and democratic environmental governance. Tokyo/New York/ Paris: United Nations University Press.

Nelson, Julie (2015). "Is dismissing environmental caution the manly thing to do? Gender and the economics of environmental protection," Ethics and the Environment, Vol. 20, No, 1, pp. 99122.

Nixon, Lindsay (2015). "Ecofeminist appropriations of Indigenous feminisms and environmental violence," thefeministwire.com, April 30.

Not Far from the Tree (2013). http://www.notfarfromthetree.org/about/what-we-do Accessed October 31, 2013.

Noveck, Beth Simone (2005). "A democracy of groups," First Monday, vol. 10, no. 11, 7 November 2005. Available at: http://firstmonday.org/ojs/index.php/fm/article/view/1289/1209 Accessed 31 October 2013.

O'Connor, Martin, ed. (1994). Is Capitalism Sustainable? Political Ecology and the Politics of Ecology. New York: Guilford Press.

Oliveira, Oscar (2004). ¡Cochabamba!: Water War In Bolivia. New York, NY: South End Press.

On the Commons (published monthly). http://onthecommons.org/

Accessed 28 October 2013.

Ostrom, Elinor (1990). Governing the commons: the evolution of institutions for collective action. New York: Cambridge University Press. 
Ostrom, Elinor (2009a). "Beyond markets and states: polycentric governance of complex economic systems." Nobel Economics Prize lecture, December 8, 9009. Available online: http://www.nobelprize.org/nobel_prizes/economic-sciences/laureates/2009/ostrom_lecture.pdf Accessed October 28, 2013.

Ostrom, Elinor (2009b). "A Polycentric Approach for Coping with Climate Change." http://www10.iadb.org/intal/intalcdi/PE/2009/04268.pdf

Ostrom, Elinor (2012). The future of the commons: Beyond market failure and government regulation. London: Institute of Economic Affairs.

Our Sustenance (2018). http://oursustenance.ca/

Paavola, J., Adger, W. N., \& Huq, S. (2006). Multifaceted justice in adaptation to climate change. In: Adger, W. N. et al., Fairness in Adaptation to Climate Change, Cambridge, MA/London, UK: MIT Press, pp. 263-278.

Parkdale Neighbourhood Land Trust (2018). http://www.pnlt.ca/about/

Pettengell, C. (2010). Climate Change Adaptation: Enabling people living in poverty to adapt. Oxfam International Research Report, Oxford: Oxfam International, http://publications.oxfam.org.uk/results.asp?sf1=contributor\&st1=Catherine $\% 20$ Pettengell\&TA $\mathrm{G}=\& \mathrm{CID}=$

Postmes, Tom (2015). "Psychology: climate change and group dynamics," Nature Climate Change

Programa Brasil Quilombola (2013). Guia de políticas públicas para comunidades quilombolas. Brasília. http://www.seppir.gov.br/portal-antigo/arquivos-pdf/guia-pbq

Quarter, Jack, Ann Armstrong and Laurie Mook, eds. (2009). Understanding the Social Economy: A Canadian Perspective. Toronto: University of Toronto Press.

Ricoveri, Giovanna (2013). Nature for sale: the commons versus commodities. London: Pluto Press.

Rowe, Jonathan (2008). "The parallel economy of the commons." State of the World Report 2008. Available online: http://jonathanrowe.org/the-parallel-economy-of-the-commons Accessed October 29, 2013.

Salleh, Ariel, ed. (2009). Eco-sufficiency and Global Justice: Women Write Political Ecology. New York: Pluto Press.

Shimada, Daisaku (2010). "How can societies create common access to nature? The roots and development process of the Bruce Trail, a Canadian case study." Post-doctoral research paper, York University Faculty of Environmental Studies. 
Simpson, Leanne Betasamosake (2017). As we have always done: Indigenous freedom through radical resistance (Milwaukee: University of Minnesota Press).

Shragge, Eric (1997) Community Economic Development: In Search of Empowerment (Montreal: Black Rose Books).

Spence, Alexa and Nick Pidgeon (2010). "Psychology, climate change and sustainable behaviour," Environment: Science and Policy for Sustainable Development, Vol. 51, Iss. 6, pp. 8-18. http://eprints.nottingham.ac.uk/2250/1/Psychology

Swift, Richard (2014). "The commons as a fount of hope," The Bullet, E-bulletin No. 1006, July 9, 2014, n.p.

Sundaresan, Jayaraj (2011). "Planning as commoning: Transformation of a Bangalore lake," Economic and Political Weekly, vol. XLVI, No. 50, pp. 71-79.

Thompson, Edward P. (1993). Customs in common. New York: The New Press.

Trosper, Ronald L. (2009). Resilience, Reciprocity, and Ecological Economics: Northwest Coast Sustainability (London / New York: Routledge).

Tuck, Eve and K. Wayne Yang (2012), “Decolonization is not a metaphor,” Decolonization: Indigeneity, Education and Society, vol. 1, pp. 1-40.

Turchin, Peter (2013). "The strange disappearance of cooperation in America," Cliodynamica. http://peterturchin.com/cliodynamica/strange-disappearance/

Turner, Matthew (2011). "Political ecology III: The commons and commoning," Progress in Human Geography, Vol. 41, Iss. 6, pp. 795-802.

Turner, Terisa E. and Leigh S. Brownhill (2001). "Gender, feminism and the civil commons: women and the anti-corporate, anti-war movement for globalization from below," Canadian Journal of Development Studies 22:4, 805-818.

Tyler, Stephen and Marcus Moench (2012). "A framework for urban climate resilence," Climate and Development vol. 4 , iss. 4.

Umeek, E. Richard Atleo (2011. Principles of Tsawalk: An Indigenous Approach to Global Crisis (Vancouver: UBC Press).

Vaughan, Genevieve (2007). Women and the Gift Economy (Toronto: Inanna Publications).

Weston, Burns H. \& David Bollier (2013) Green Governance: Ecological survival, human rights, and the law of the commons. Cambridge: Cambridge University Press. 
World March of Women (2009). "The common good and public services," http://www.marchemondiale.org/actions/2010action/text/biencomun/en/base_view

YIMBY (2018). http://thestop.org/find-your-garden-match/

This paper draws from several earlier papers:

"Commons and climate justice," presented as part of a panel on 'Living with Climate Change through Commons Governance' organized by Prateep Kumar Nayak at the Biennial Conference of the International Association for Study of the Commons, Edmonton, Alberta, May 25-29, 2015;

"Climate Justice and Gender Justice: Building women's political agency in times of climate change" given at the IAFFE conference in Accra, Ghana (2014);

"Building Commons Governance For A Greener Economy,” published in Mitchell 2014;

and my plenary talk from the CANSEE 2013 conference in Toronto. 